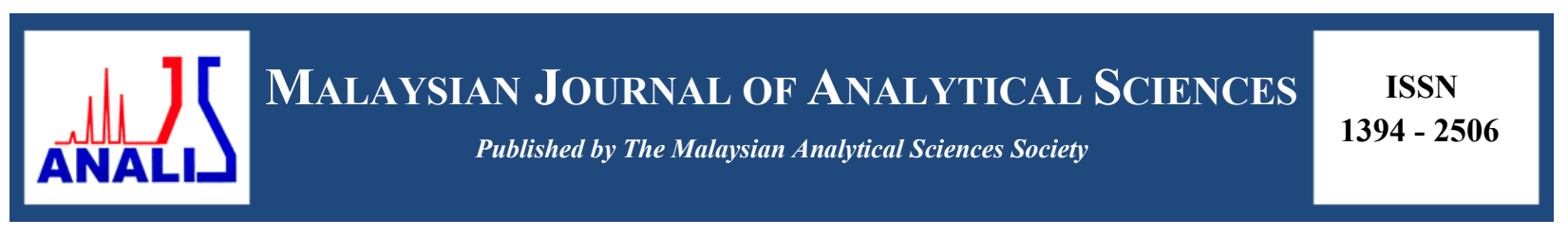

\title{
PREPARATION AND CHARACTERIZATION OF EPOXIDISED NATURAL RUBBER (ENR)/POLY (VINYLIDENE FLUORIDE) (PVDF) (ENR/PVDF) COMPOSITE MEMBRANE
}

\author{
(Penyediaan dan Pencirian Membran Komposit Getah Asli Terepoksida (ENR) / Poli \\ (Vinilinida Fluorida) (PVDF) (ENR/PVDF) \\ Norliyana Mod ${ }^{1}$, Farah Hannan Anuar ${ }^{1,2}$, Rizafizah Othaman ${ }^{1,2 *}$

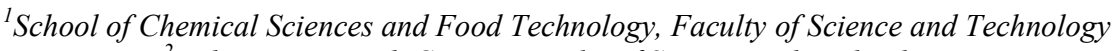 \\ ${ }^{2}$ Polymer Research Center, Faculty of Science and Technology \\ Universiti Kebangsaan Malaysia, 43600 UKM Bangi, Selangor, Malaysia \\ *Corresponding author: rizafizah@ukm.edu.my
}

Received: 10 June 2015; Accepted: 21 July 2016

\begin{abstract}
The focus of this research is to prepare epoxidised natural rubber (ENR)/poly(vinylidene fluoride) (PVDF) (ENR/PVDF) membrane using solution casting method and to characterize the ENR/PVDF membrane using universal tensile machine (UTM) and scanning electron microscope (SEM). Composite membrane of ENR/PVDF was prepared by solution casting technique. The tensile strain increases when ratio of ENR increases in the composite. SEM micrograph shows the compatibility of ENR and PVDF in 40/60 wt\% sample but agglomeration of ENR in 60/40 wt\% ENR/PVDF sample was observed. The micrograph also shows the existence of pores in the composite membrane which is essential when applying the membrane for separation of gas and waste water treatment.
\end{abstract}

Keywords: composite membrane, epoxidised natural rubber, poly(vinylidene fluoride)

\section{Abstrak}

Fokus kajian ini adalah untuk menyediakan membran getah asli terepoksida (ENR)/ poli (vinilidina fluorida) (PVDF) (ENR/PVDF) menggunakan kaedah penuangan larutan dan untuk mencirikan membran ENR/PVDF menggunakan mesin ujian tensil (UTM) dan mikroskop imbasan elektron (SEM). Membran komposit ENR/PVDF telah disediakan menggunakan teknik penuangan larutan. Rintangan tegangan bertambah apabila ratio ENR bertambah didalam komposit. Mikrograf SEM menunjukkan kesesuaian ENR dan PVDF pada sampel 40/60 wt\% tetapi terdapat penggumpalan ENR pada sampel ENR/PVDF 60/40 wt\%. Mikrograf juga menunjukkan kehadiran liang pada membran komposit tersebut dimana ianya penting untuk diaplikasikan sebagai membran pemisahan gas dan rawatan air buangan.

Kata kunci: membran komposit, getah asli terepoksida, poli (vinilidina fluorida)

\section{Introduction}

Polymer composite is formed when two or more polymers are combined together using various methods such as internal mixture and solution blending. This combination becomes more attentive in polymer industries because it can improve the properties of individual polymer at the end of the process. Combination between thermoplastic polymer and rubber, or known as thermoplastic rubber (TPR) exhibits the properties of elastomeric materials with the possibility of thermoplastic at ambient temperature [1]. Membrane is one of the examples of materials that can 
be made from composite polymer. It can be prepared by using solution casting and solvent exchange method. Membrane is a layer that allowed permeation and selectivity of fluid to happen and it usually has a porous support layer to provide mechanical strength to the membrane [2]. Many industries use membrane for the separation of wastewater and gas. The advantages of using membrane are minimum energy of processing, no addition of chemical, environmental friendly and efficient treatment [3].

The combination of epoxidised natural rubber (ENR) with thermoplastic poly (vinylidene fluoride) (PVDF) using internal mixture at high temperature has been reported before [4]. It is found that the tensile strength of PVDF decreased with increasing ENR. PVDF has the properties of high initial modulus, which is brittle and need to be applied as composite. PVDF has many applications as membranes in industries including microfiltration (MF), ultrafiltration (UF), gas separation and pollutant removal from waste water because of the chemical resistivity, thermal stability, and easy to dissolve in variety of solvent. Besides, PVDF is a semi-crystalline polymer, which has different phases of crystallinity named $\alpha$ (form II), $\beta$ (form I), and $\gamma$ (form III) [5]. Phases of crystal can be controlled in various ways; such as suitable solvent [6], temperature [7,8], and addition of additive $[9,10]$. ENR is natural rubber which has undergone the addition of epoxide group in the chains by performic epoxidation [11]. ENR is elastic good in tensile strength, oil resistance, and permeable to gas.

Solubility parameter or miscibility between solvent and solute is very important to make composite solution for membrane. The compressibility of solution will be less than that of solvent, so the solute will gain mobility and have some probability of contracting the solvent molecule [12]. Mixing of solvent between tetrahydrofuran (THF) and N,N-Dimethylacetamide (DMAC) has been reported Bagheripour et. al. [13]. THF was used to increase the phase separation time in coagulation bath and preventing macro voids. In current research, PVDF is not soluble in THF. Thus, DMAC was used to make PVDF soluble before combining with ENR. The solubility parameter of each solvent is displayed in Table 1. When the solubility parameter increases, it will be easier for the solvent to dissolve the solute and the non-solvent will be more able to diffuse in membrane casting. So, the exchange of solvent and non-solvent in coagulation bath will be faster and lead to the formation of pores.

The objectives of this paper are to prepare ENR/PVDF membrane in different ratios using solution casting method and to characterize the ENR/PVDF membrane using universal tensile machine (UTM) and scanning electron microscope (SEM). The possibility of using the ENR/PVDF composite as membrane will be discussed.

Table 1. Solubility Parameters

\begin{tabular}{lc}
\hline Solvent & Solubility Parameter $(\boldsymbol{\delta})$ \\
\hline THF & 11.44 \\
DMAC & 11.13 \\
Water & 9.4 \\
THF/DMAC $(57 / 43$ vol $\%)$ & 11.30 \\
\hline
\end{tabular}

\footnotetext{
Materials

Epoxidised natural rubber with 50\% mol of epoxidation level, ENR-50 (Mw $=640000 \mathrm{~g} / \mathrm{mol})$ was obtained from Rubber Research Institute of Malaysia (RRIM). PVDF (Mw $=543000 \mathrm{~g} / \mathrm{mol}$ ) in powder form was purchased from Sigma-Aldrich (M) Sdn. Bhd. Tetrahydrofuran (THF) $(\mathrm{Mw}=72.11 \mathrm{~g} / \mathrm{mol})$ with $99.8 \%$ purity was purchased from Systerm Sdn. Bhd. N,N-Dimethylacetamide (DMAC) with 99\% purity was purchased from Merck. Distilled water was used in coagulation bath for exchanging between solvent and non-solvent.
}

Materials and Methods 


\section{Membrane preparation}

ENR/PVDF membrane was prepared using different ratios (0/100 wt $\%, 20 / 80 \mathrm{wt} \%, 40 / 60 \mathrm{wt} \%$, and $60 / 40 \mathrm{wt} \%$ ) by solution casting technique. ENR was swelled in THF for 24 hours before vigorously stirred until homogeneous solution was produced. At the same time, PVDF was stirred in DMAC solution in separate container until homogenous. Then, the solution was mixed and continuously stirred for 3 hours. The membrane solution was then degassed for one night to eliminate bubbles. Solution casting was done on a glass plate using a casting knife to get a membrane. After 2 minutes, the membrane was immersed in distilled water for solvent exchange to occur until the white solid membrane formed. Lastly, the sample was dried at ambient temperature and kept in desiccators before testing. The average thickness of the membrane after drying was about $0.02 \mathrm{~mm}$.

\section{Membrane characterization}

The membrane had been characterized as follows:

\section{(a) Universal tensile machine (UTM)}

The tensile strength of the membrane was measured using Zwick Roell universal tensile machine, Z1.0 model at jogging rate of $50 \mathrm{~mm} / \mathrm{min}$. Membranes were tested according to ASTM D412. Prior to that, the samples were cut into the standard dumbbell shape using hollow die punch at ambient temperature. For each membrane, five replications were used and their average values were reported.

\section{(b) Scanning electron microscope (SEM)}

The surface morphology of the membrane was obtained by using variable pressure scanning electron microscope (VPSEM) with energy dispersion X-ray (EDX). The model is ZEISS EVO MA 10 (UK) with EDAX Apollo X (USA). The sample was sputter coated with gold before analysis and the magnification used was $5000 \times$.

\section{Results and Discussion}

Figure 1 (a) is the appearance of the ENR/PVDF membrane. The colour of the membrane solution becomes dark brown when the colourless solution of PVDF was added into the ENR solution. After the sample was dried at room temperature, it turned into a transparent film as can be seen in Figure 1 (b). The thickness during casting was 0.15 $\mathrm{mm}$ and $0.02 \mathrm{~mm}$ after it dried. The solvent evaporated from the membrane, resulting to reduce of the overall thickness.
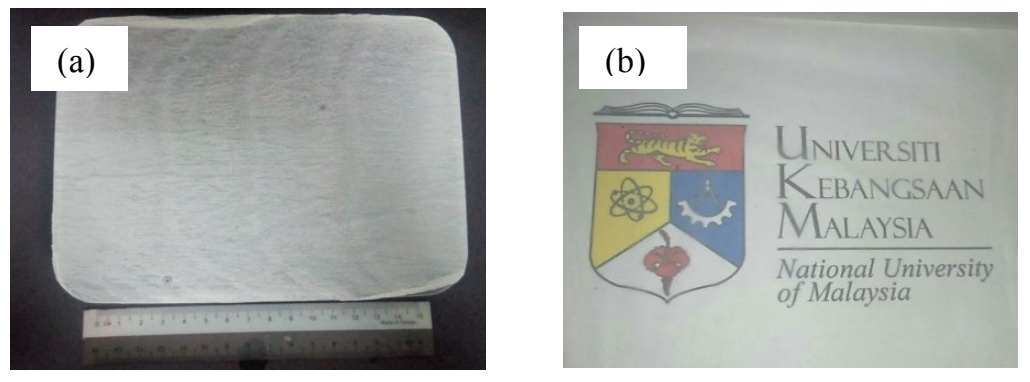

Figure 1. ENR/PVDF membrane for ratio $60 / 40 \mathrm{wt} \%$

\section{Mechanical properties}

Tensile stress is the resistance of a material towards the force per unit area to the point to tear it apart. While tensile strain is deformation of a solid due to stress that applied. Table 2 shows that the tensile stress decreases with increasing ratio of ENR due to the sample cannot withstand with the force applied. The tensile strain, on the other hand increased. As mentioned before, PVDF is a brittle polymer which is easy to tear apart. Decreasing the ratio of PVDF caused the tensile strain to increase and the addition of ENR introduced a greater chain movement in the membrane. Molecular chain of the sample kept it in metastable state between the amorphous and crystalline states. 


\section{Norliyana et al: PREPARATION AND CHARACTERIZATION OF EPOXIDISED NATURAL RUBBER (ENR)/POLY (VINYLIDENE FLUORIDE) (ENR/PVDF) COMPOSITE MEMBRANE}

Table 2. Tensile stress and tensile strain for ENR/PVDF membrane with different composition

\begin{tabular}{lcc}
\hline $\begin{array}{l}\text { ENR/PVDF Membrane } \\
\text { (wt\%) }\end{array}$ & $\begin{array}{c}\text { Tensile Stress } \\
\text { (MPa) }\end{array}$ & $\begin{array}{c}\text { Tensile Strain } \\
(\mathbf{\%})\end{array}$ \\
\hline $20 / 80$ & 3.92 & 8.26 \\
$40 / 60$ & 1.72 & 14.82 \\
$60 / 40$ & 1.40 & 15.90 \\
\hline
\end{tabular}

\section{Surface morphology}

Figure 3 shows the physical images of ENR/PVDF membrane with different compositions of ENR and PVDF. The micrographs show that pores are present on the surface of all membranes. Random pores were formed due to the property of PVDF and the exchange between solvent and non-solvent during solvent-exchange process. The average pore size for the membranes is shown in Table 3. The pore size increased with the increase ratio of ENR which proven that the addition of ENR caused more chain movement which caused bigger pores on the membrane. This is in a good agreement with previous reported study [14]. For the 60/40 wt\% sample (Figure 3c), it can be seen that surface is not even which is due to the agglomeration of ENR in the composite. However, the same problem was not observed on 40/60 wt\% (Figure 3b) which make it suitable to be applied as membrane as pores and high tensile strain were observed.

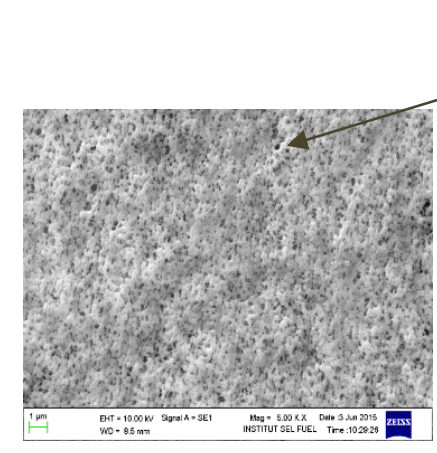

(a) $0 / 100 \mathrm{wt} \%$

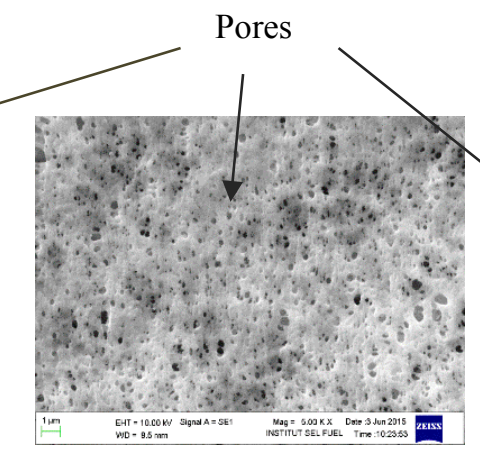

(b) $40 / 60 \mathrm{wt} \%$

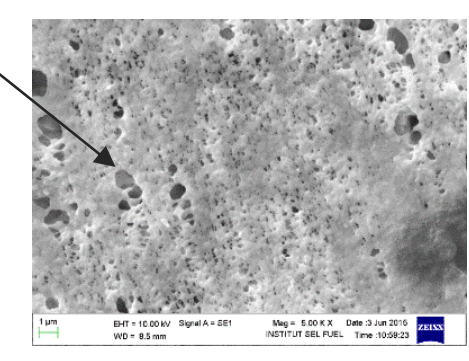

(c) $60 / 40 \mathrm{wt} \%$

Figure 3. Scanning electron micrographs of surface for ENR/PVDF at magnification $\times 5000$

Table 3. Average pore sizes of the ENR/PVDF membranes

\begin{tabular}{lc}
\hline $\begin{array}{l}\text { ENR/PVDF Membrane } \\
(\mathbf{w t} \%)\end{array}$ & $\begin{array}{c}\text { Average pore size } \\
\text { (nm) }\end{array}$ \\
\hline $0 / 100$ & $89.32-268.9$ \\
$40 / 60$ & $157.9-625.7$ \\
$60 / 40$ & $271.7-861.9$ \\
\hline
\end{tabular}

\section{Conclusion}

As conclusion, ENR/PVDF membrane with different ratios can be prepared by using solution casting method. The thickness of the membrane during casting was $0.15 \mathrm{~mm}$ and the average thickness after dried was $0.02 \mathrm{~mm}$. SEM micrographs showed the agglomeration of ENR in the ENR/PVDF solution with the ratio of $60 / 40 \mathrm{wt} \%$ because of 
the immiscibility between ENR and PVDF but the 40/60 wt $\%$ membrane did not show any incompatability. The increasing ratio of ENR in PVDF had caused the tensile strain to increase and the tensile stress to decrease. Due to the porosity and the tensile property of $40 / 60 \mathrm{wt} \%$ ENR/PVDF composite, it has the potential to be applied to as membrane for gas separation and pollutant removal from wastewater.

\section{Acknowledgement}

The authors gratefully acknowledge the financial support from FRGS/2/2013/TK06/UKM/02/1 and 03-01-02SF1115. We also would like to deliver our grattitude towards Universiti Kebangsaan Malaysia (UKM), Polymer Research Center (PORCE) and SELFUEL, UKM.

References
1. Salaeh, S., Nakason, C., Boiteux, G. and Cassagnau, P. (2013). Co-continuous phase structure and properties of poly(vinylidene fluoride)/epoxidized natural rubber blends. Advanced Materials Research, 626: 71 - 74.

2. Bottino, A., Camera-Roda, G., Capannelli, G. and Munari, S. (1991). The formation of microporous polyvinylidene difluoride membranes by phase separation. Journal of Membrane Science, 57: 1 -20.

3. Yan, L., Hong, S., Li, M. L. and Li, Y. S. (2009). Application of the $\mathrm{Al}_{2} \mathrm{O}_{3}-\mathrm{PVDF}$ nanocomposite tubular ultrafiltration (UF) membrane for oily wastewater treatment and its antifouling research. Separation and Purification Technology, 66: 347 - 352.

4. Salaeh, S. (2014). Processing of natural rubber composites and blends: Relation between structure and properties. PhD dissertation, Prince Of Songkla University (Psu) - Pattani (Thailand).

5. Hasegawa, R., Takahashi, Y., Chatani, Y. and Tadokoro, H. (1972). Crystal structures of three crystalline forms of poly(vinylidene fluoride). Polymer Journal, 3: $600-610$.

6. Boccaccio, T., Bottino, A., Capannelli, G. and Piaggio, P. (2002). Characterization of PVDF membranes by vibrational spectroscopy. Journal of Membrane Science, 210: 315 - 329.

7. Tao, M.-M., Liu, F., Ma, B.-R. and Xue, L.-X. (2013). Effect of solvent power on PVDF membrane polymorphism during phase inversion. Desalination, 316: $137-145$.

8. Wang, X., Zhang, L., Sun, D., An, Q. and Chen, H. (2009). Formation mechanism and crystallization of poly(vinylidene fluoride) membrane via immersion precipitation method. Desalination, 236: 170 - 178.

9. Sulaiman, N. M. N. and Ling, C. K. (2004). Membrane ultrafiltration of treated palm oil mill effluent (POME). Jurnal Teknologi, 41(1): $113-120$.

10. Cao, X., Ma, J., Shi, X. and Ren, Z. (2006). Effect of $\mathrm{TiO}_{2}$ nanoparticle size on the performance of PVDF membrane. Applied Surface Science, 253: 2003 - 2010.

11. Yoksan, R. (2008). Epoxidized natural rubber for adhesive applications. Kasetsart Jurnal (Natural Science), 42: $325-332$.

12. Sharma, S. K., Singh, G., Kumar, H. and Kataria, R. (2015). Study of solute-solute and solute-solvent interactions of $\mathrm{N}$-acetyl glycine in aqueous $\mathrm{D}$-fructose solutions at different temperatures. Thermochimica Acta, 607: $1-8$.

13. Bagheripour, E., Moghadassi, A. R. and Hosseini, S.M. (2014). Novel nanofiltration membrane with low concentration of polyvinylchloride: Investigation of solvents' mixing ratio effect (dimethyl acetamide/tetrahydrofuran). Arabian Journal of Chemistry, $1-6$.

14. Jon, N., Abdullah, I. and Othaman, R. (2013). Effects of silica on the formation of epoxidised natural rubber/polyvinyl chloride membrane. Sains Malaysiana, 42(4): 469 - 473. 